\title{
Introducing the first articles of the veterans and military patient-related health outcomes thematic series
}

This article was published in the following Dove Medical Press journal:

Patient Related Outcome Measures

\author{
Liana DesHarnais Castel ${ }^{1,2}$ \\ 'Lundy-Fetterman School of Business, \\ Campbell University, Buies Creek, \\ NC, USA; ${ }^{2}$ Clinical Performance \\ and Quality, Cigna Health and Life \\ Insurance Company, Raleigh, NC, USA
}

Correspondence: Liana DesHarnais Castel

Lundy-Fetterman School of Business,

Campbell University, P O Box 218, Buies

Creek, NC 27506, USA

Email castel@campbell.edu
Modern medicine and scientific research owe a special debt to the care and well-being of service personnel who endure, sometimes multiple, deployments in times of war and conflict. The intense nature of violent conflict, isolation and distance from their family and home, and exposure to harsh conditions and chemicals puts these populations at risk for both acute and chronic, often lifelong adverse patient-related physical and mental health outcomes.

In 2018 the Editors of Patient Related Outcome Measures launched a Thematic Series entitled Veterans and Military Patient-Related Health Outcomes, seeking to publish research studies in topics concerning veterans and military health. We invited studies that identify and measure clinically relevant outcomes cross-sectionally and longitudinally, as well as studies to identify the effectiveness of interventions to improve patient-related outcomes in veterans and military service personnel.

In this Thematic Series, Hahn et al reported the development and validation of a patient-reported outcome measurement system for caregivers of civilians or service members/veterans with traumatic brain injury, investigating the acceptability of a computer-based survey administration platform among caregivers. The study discerned important considerations for surveying outcomes among caregivers of United States service members. ${ }^{1}$ Also, in the domain of instrument development, Gutierrez et al discussed the creation and content validity of the Military Concussion Readiness Inventory for Dizziness and Balance, which they developed to recognize functional impairments of dizziness and balance in service members who experienced a mild blast- or non-blastrelated traumatic brain injury. ${ }^{2}$ In a study highlighting both the persistence of symptoms and the importance of social support, Pereira et al examined family, personality, and social support variables as predictors of post-traumatic stress symptoms and quality of life in Portuguese veterans who participated in the Colonial War (1961-75). ${ }^{3}$

We invite researchers to take advantage of data at their institutions and available online in patient-related mental and physical health outcomes relevant to military deployment and reintegration including, but not limited to, the following examples:

- exposure to factors encountered in combat (eg, burn pits, chemical weapons);

- opioid safety;

- fitness and wellness;

- spinal cord and traumatic brain injury; 
- quality of care from the serviceperson standpoint, including satisfaction ratings and qualitative research on areas where veteran care needs improvement.

Please submit your work for consideration for the Veterans and Military Patient-Related Health Outcomes Thematic Series.

\section{Disclosure}

Professor Castel is the Editor in Chief for Patient Related Outcome Measures, an open access journal with Dove Medi- cal Press. The author reports no other conflicts of interest in this work.

\section{References}

1. Hahn EA, Ianni PA, Hanks RA, et al. Survey response burden in caregivers of civilians and service members/veterans with traumatic brain injury. Patient Relat Outcome Meas. In press 2019.

2. Gutierrez ML, Christy JB, Whitney SL. Development of military concussion readiness inventory for dizziness and balance. Patient Relat Outcome Meas. In press 2019.

3. Pereira MG, Machado JC, Pereira M, Lopes C, Pedras S. Quality of life in elderly Portuguese war veterans with post-traumatic stress symptoms. Patient Relat Outcome Meas. In press 2019.

Dove Medical Press encourages responsible, free and frank academic debate. The content of the Patient Related Outcome Measures 'Editorial' section does not necessarily represent the views of Dove Medical Press, its officers, agents, employees, related entities or the Patient Related Outcome Measures editors. While all reasonable steps have been taken to confirm the content of each Editorial, Dove Medical Press accepts no liability in respect of the content of any Editorial, nor is it responsible for the content and accuracy of any Editorial.

Patient Related Outcome Measures

\section{Publish your work in this journal}

Patient Related Outcome Measures is an international, peer-reviewed, open access journal focusing on treatment outcomes specifically relevant to patients. All aspects of patient care are addressed within the journal and practitioners from all disciplines are invited to submit their work as well as healthcare researchers and patient support groups.
Dovepress

The journal is included in PubMed. The manuscript management system is completely online and includes a very quick and fair peer-review system. Visit http://www.dovepress.com/testimonials.php to read real quotes from published authors.

Submit your manuscript here: http://www.dovepress.com/patient-related-outcome-measures-journal 